\title{
THE SOCIAL WORK RESEARCH MODULE(S) FROM A SOCIAL WELFARE PERSPECTIVE
}

\section{Herman Strydom}

\section{INTRODUCTION}

A once-off qualitative questionnaire was sent via e-mail to the social work various training institutions in South Africa. Various topics were covered in the empirical study and as far as possible theoretical substantiation of the findings were integrated with the findings. Topics such as the views of the lecturers and the students on the importance of the research module(s), number of credits allotted to the research module(s), the level of presentation, the limitations/challenges experienced in the operationalising of the research module(s), the link between the theoretical and empirical parts of the module(s), the various study units, and whether students do their research projects individually, in pairs or in groups were covered in this questionnaire.

\section{PROBLEM STATEMENT}

Research has always been neglected in service delivery, whether in casework, group work or community work. Many students demonstrate resistance to doing research and in particular the research module(s) offered to them as part of their training as social workers. Practitioners have often raised the argument of being too busy to indulge in research activities. However, lately it has been realised by many social workers that, without proper research, no service delivery can take place and that research should form part of all endeavours to improve the quality of life for everybody in the context of social work, and to enable every trained social worker to be a proper accountable, scientific researcher and practitioner (Bloom, Fischer \& Orme, 1999:1415; Everitt, Hardiker, Littlewood \& Mullender, 1992:16-17; Monette, Sullivan \& DeJong, 2005:3-4).

Although most academically inclined social workers agree on the importance of research in everyday functioning in practice and for the standing of the profession amongst other professions, there is still no agreement on what should be included or excluded in the research module(s). Students have mixed feelings about the research module(s) and many see research as an unnecessary evil that they merely have to cope with, without seeing the real importance and place of research in their curriculum, although research training for social workers has made noteworthy progress over the years (Gibbs, 2001; Sales, Lichtenwalter \& Fevola, 2006:543). Research modules have varying degrees of importance, and there is also a high degree of diversity in the kinds of training these modules provide among the various schools of social work; negative attitudes towards research are also often transmitted by educators (Dunlap, 1993:300; Strydom, 1998a:65). This has resulted in a lack of progress in social work research in South Africa (Strydom, 1997:121).

\begin{abstract}
AIM
The aims of this study are: to ascertain the reasons for the reluctance among students and lecturers to study or present the research module(s); to suggest a number of credits and level of presentation; to indicate the limitations experienced in the operationalising of these modules; to suggest content for these modules; and to explore whether students should execute individual or group projects.
\end{abstract}


From these overarching aims the following objectives can be formulated:

- To ascertain the viewpoints of participants on the importance of the research module(s);

- To determine students' views on the importance of the research module(s) as envisaged by participants;

- To make suggestions regarding the number of credits, the level of presentation and whether the research projects of students should be conducted at an individual or group level;

- To study the limitations experienced in the operationalising of the research modules; and

- To suggest content for the research module(s).

\section{RESEARCH METHODOLOGY}

Survey research (Hesse-Biber \& Leavy, 2006:377-378; Kirk, 1999:191-192) was utilised as the research procedure for this study. A self-administered questionnaire (Bless \& Higson-Smith, 2000:105-106; Glicken, 2003) was developed and distributed via e-mail to all South African training institutions where social workers are educated. The study was of an exploratory nature (Morris, 2006:11-12) and the lecturer responsible for the research module(s) at each of the institutions was requested to complete the mainly qualitative questionnaire (De Vos, Strydom, Fouché \& Delport, 2005:373).

The total population of 17 institutions was utilised, thus no sampling procedures had to be implemented (Druckman, 2005:140-141). First-time responses were received from 8 institutions, while the others had to be reminded. After the reminder was sent out, 6 more institutions replied. In total $14(82,4 \%)$ questionnaires were returned, which can be regarded as excellent (Grinnell \& Williams, 1990:217). But perhaps this response rate is not so good, considering the time and effort that went into contacting the various schools of social work. Validity and reliability of data were considered during the entire research process (Glicken, 2003:88). The data were analysed by way of certain themes that could be extracted from the data. The usual ethical issues such as confidentiality, voluntary participation and feedback to participating institutions were taken into consideration in the study (Corey, Corey \& Callanan, 1993).

\section{TERMINOLOGY}

In order to have the same terms of reference as practitioners and researchers, the following terminology will be used.

\section{Research}

According to Barker (2003:368), research can be seen as "Systematic procedures used in seeking facts or principles." One realises that this definition can also be applicable to any other method of social work. Whether case work, group work or community work is done, one has to work systematically in order to seek facts.

\section{Social research}

Social research can be defined as follows: "A systematic investigation, using the principles of the scientific method, to test hypotheses, acquire information, and solve problems pertaining to human interrelationships" (Barker, 2003:406). Social research is done in all the social sciences such as Psychology, Sociology and Criminology. Social work research, however, narrows the field to social work specifically. 


\section{Social work research}

It is important to establish a scientific, research-based foundation of knowledge for social work by means of which information can be accumulated and transmitted to the benefit of the social work client and the larger community. Social work research can basically be described as the process aimed at investigating the theory and practice of social work (New Dictionary of Social Work, 1995:61). More empirical research is done by social workers and this tendency is evident in the growing number of empirical research articles published in social work journals (Dunlap, 1993:299). Empirical findings should, however, always be based on, anchored in, and integrated with the theoretical framework of the profession.

\section{FINDINGS}

On most topics participants gave more than one opinion. If a number is indicated after a statement, it does not refer to quantitative data; it means that more than one participant mentioned the same idea.

\section{VIEWPOINTS OF THE PARTICIPANTS ON THE IMPORTANCE OF THE RESEARCH MODULE(S)}

The following opinions can be seen as being representative of the viewpoints of lecturers on the importance of research.

- Research is very important for social workers and is a non-negotiable component of the curriculum to expose them to logical analysis of social problems and proper scientific approaches to solution seeking as well as to critical thinking and conceptualising skills. In other words, their total scientific foundation relies on the research modules. It is so important that lecturers can cut down on other theoretical modules. (9)

- It enables social workers to believe in their ability to undertake research in practice. The course should consist of both a theoretical and a practical component, and students should receive supervision and support in their research endeavours. (5)

- Training in social work research is one of the most important aspects of instilling professionalism and a scientific orientation in students. The necessary knowledge, skills and attitude towards research is important to implement the researcher-practitioner paradigm where social workers routinely evaluate their services, become accountable to consumers and expand the knowledge basis of social work. (2)

- The researcher module is very important and should be presented by capable people who can inspire students to conduct research.

One can gather from the above-mentioned statements of research lecturers that everyone agrees on the importance of the research module(s). Various aspects have, however, been emphasised by some participants. Some of these aspects are the need for scientific practice, including skills such as critical thinking, conceptualisation, the integration of theory and practice, writing skills and accountability. Capable and enthusiastic lecturers, knowledge of research, and a positive attitude and willingness to conduct research were also mentioned.

Bloom et al. (1999:14-15) and Strydom (1998b:47-48) focus on the term scientific practitioner This has several dimensions, including using the results of research; being able to select intervention procedures that have provided evidence of effectiveness; systematic monitoring and evaluation of one's own practice with each and every case; developing the skills, attitudes and commitment to keep learning and searching for new and more effective ways of serving 
consumers; conducting practice as a problem-solving experiment in which little or nothing is assumed as known or given; and a commitment to the values of the helping professions, a sensitivity, care and concern for the well-being, rights and dignity of all clients and consumers. It is thus obvious from this definition that the notion of a scientific practitioner reaches further than conducting research only and encompasses the total practice of a social worker. The research module(s) can thus to a certain extent be seen as encompassing the total social work course.

Regarding the role of lecturers in research, more effective teaching strategies for linking research and practice should be implemented (Weinbach \& Rubin, 1980), also incorporating humour to put students at ease and to dispel anxiety about the research module(s) (Epstein, 1987). Regular homework assignments can increase performance scores, and video illustrations or case studies of complex material can enliven lectures. Research modules are of the utmost importance if the escalating social problems, increasing consumer demands and outcomedriven funding systems are taken into consideration - this should signal the need to abandon ambivalence and to restore the commitment to research (Dunlap, 1993:301).

\section{STUDENTS' VIEWS ON THE IMPORTANCE OF THE RESEARCH MODULE(S) AS ENVISAGED BY PARTICIPANTS}

The following remarks were made concerning the issue of students' viewpoints on the importance of the research module(s). Respondents could give more than one opinion on this topic.

- Students realize that 32 credits form a significant component of their degree structure and the module automatically assumes significance in the eyes of the student. (5)

- Research is initially regarded as one of the very difficult courses that one has to dislike, but simply has to work through. (5)

- A number of respondents see it as a necessary hazard of the programme. Some see it as one of 'those' courses, while others see it as an exciting endeavour that can help them to integrate theory with practice. (3)

- In the end most students feel empowered and express satisfaction and desire to proceed with research in the future and to explore postgraduate options. (2)

- The lecturer has to indicate the rationale for research in social work and should be positive about teaching research. (2)

- Students hold stereotypes regarding research and are of the opinion that the content is abstract, time consuming and irrelevant. (2)

- The majority of students do not regard the research module(s) as important, seeing that their focus, while studying social work, is primarily on the implementation of the primary methods of social work and not on conducting research. Their opinion about helping people is often far removed from research and does not fit into this paradigm. (2)

- Students have to overcome their fear of research before it can become a positive experience to them.

- Fourth-year students often convey negative perceptions to the other year groups and, by the time they reach the fourth year, they are already negatively predisposed to research.

Many reasons can be given for the initial negative attitude and the anxiety of students about the research module(s). Some of these reasons can be the negative message that fourth-year 
students convey to younger students, that research is not part of helping people, and that research is difficult and abstract. Even practitioners often do not have the self-confidence to execute research and it was found that $54 \%$ of participants in the study of Strydom (1997:127) lacked the self-confidence to undertake research in their daily practice. Karger (1983) questioned whether all students have the ability to execute complex quantitative research designs. Students have to execute research as part of their course, but once in practice not many graduates use research findings (Tripodi \& Epstein, 1978). Fortunately this has changed and a large percentage $(89 \%)$ of participants in the study by Strydom (1997:122) indicated that they have already been involved in one or more research projects.

The general perception gained from the statements is that, after breaking through the initial barriers, students find the module(s) empowering, that it helps them to integrate theory with practice and that some even see it as an exciting endeavour. Strydom (1997:130) found that $23 \%$ of social work practitioners in his study mentioned that research and practice should not be combined. Hesse-Biber and Leavy (2006:96) mention that most people either love or hate research, and are either energised by gathering data and analysing findings, or think that research is too far separated from real-life situations.

In many universities and colleges research continues to be an unpopular subject with students. Drawing upon 20 years of teaching experience in social work research modules, Epstein (1987:71) noted: "No other part of the social work curriculum has been so consistently received by students with as much groaning, moaning, eye-rolling, hyperventilation and waiverstrategising as the research courses." She concluded that resistant pupils are reluctant learners. Because of this resistance to the research module(s), research lecturers have to teach in a creative and innovative manner.

\section{NUMBER OF CREDITS ALLOCATED, AND TERM, SEMESTER AND LEVEL OF STUDY OF THE RESEARCH MODULE(S)}

In this question participants had to discuss the number of credits, as well as the term, semester and level at which the research module(s) is conducted.

- At level four, 32 credits throughout the year. (6)

- Twelve credits for theory and 12 for the practical work. During the fourth year. (3)

- Three modules of 16 credits each equals 48. Second semester third year and first semester fourth year.

- Eighteen credits for theory and 18 for the practical work. Second semester third year and first semester fourth year.

- Seven credits for theory and 20 for the practical work.

- Eight credits in the third year and 16 credits in the fourth year.

- Ten credits for theory and 10 for the practical work.

- Only 15 credits in the third term of the third year.

- The third-year course on research in combination with the module on values and ethics. The total module will be 34 credits. The fourth-year module is not modularised. The theoretical part forms part of Social Work Theory and Practice, while the research report is a year-long course (small-scale research project).

- We do not use credits at this stage, but have a semester course in the third year and a semester course in the fourth year, plus a mini-dissertation. 


\section{- No response.}

From these responses one can deduce that a large range of credits is currently allotted to the research module(s), which supports the finding that there is a wide range of diversity in the content of the research modules of the various schools of social work (Strydom, 1998a:65). This is currently being addressed by the National Social Work SGB and the benchmarking of exit-level outcomes by the South African Council for Social Service Professions. The number of credits currently ranges from three modules of 16 each, thus 48 credits to only 15 in the third term of the third year. The author's personal view on the ideal number of credits for the research module(s) would be 8 credits at level 3, and 16 at level 4. Most institutions offer their research module(s) at level 4 only. Students should start with research in the second semester of the third year and continue in the first semester of the fourth year. In this way research can form a continuous process across the span of a total year. If a research module can be introduced to third-year students instead of only starting in the fourth year, one can ensure that research is not a totally new endeavour for the final-year students. Overall the fourth year is too labour intensive as it is, and to introduce research only at level four maintains and deepens the reluctance students feel towards research, in any case.

\section{THE LIMITATIONS/CHALLENGES EXPERIENCED IN THE OPERATIONALISING OF THE RESEARCH MODULE(S)}

The following are some of the limitations/challenges experienced by lecturers in the operationalising of the research module(s).

- Students lack basic critical and analytical thinking skills, basic vocabulary and in many cases language skills (English is a third or fourth language in many cases) and they also lack formulation and writing skills. Students are basically poorly prepared academically. (8)

- Many students lack interest and have a negative perception of research. (3)

- Classes have become larger since our merger; consequently teaching as well as supervision and support of learners have accordingly become more difficult. (3)

- Time limitations. The fourth year is overwhelming to many students, seeing that they then have to do so many things for the first time. Fourth-year students are expected to complete their research projects in less than 12 months and even in some cases within one semester. This causes major anxiety. (3)

- Plagiarism has become a major problem and students are not properly educated to treat academic property with care. (3)

- Welfare organisations do not possess a research culture and are therefore unable to motivate students to become proper practitioner-researchers. (3)

- Even lecturers who conduct the module(s) are not always committed to research themselves. Not all lecturers are up to standard regarding research, and are not always interested, but nevertheless have to motivate students for the research module! Teaching loads are heavy and devoting time to research is an additional challenge. Staff members are not always willing to supervise students doing their research projects. (3)

- Very little research is done in the other subjects and often they only have the social work research module(s). When one asks a third/fourth-year student whether they have done courses in research in the other subjects, they would answer positively, and yet they are still ignorant as to research methodology. 
- It is difficult for three to four supervisors to supervise 66 students. Students must, however, be enlightened about the entire research process and also for the master's degree.

- Students struggle to work independently. They lack confidence and initiative to conduct research.

- Because of the increase in student numbers we are forced to pair students for their research projects.

- We use group projects, but the challenge is to ensure that everybody is at the same level regarding the expectations and knowledge basis. Not all students put the same amount of effort into their projects and lean heavily on the industrious students but gain the same mark in the end. This is thus also not a satisfactory situation.

- Delays in obtaining ethical permission from the institution as well from relevant authorities, such as the Department of Health or of Education, for undertaking the projects before students can commence with their research is a huge draw-back.

Besides the lack of writing skills and command of language, most students are only prepared to write once without pre-writing, composing, re-writing, re-thinking or even re-reading - as a matter of fact they do free-writing and consider it to be the final product. Students are also not sceptical and open-minded about what they read and find in their studies; often they are not creative and productive researchers - thus a general lack of research-mindedness and lack of what is needed to be a researcher prevails. This was even found by authors in an international context such as Mitchell and Jolley (2001:6-9) and Neuman (2003:473).

Plagiarism has also become a major problem, especially regarding internet sources. Individual guidance on research projects is the ideal, but in the case of large groups of students it is very difficult and often even out of the question. It is evident that the fourth year of study is a full year and is even overwhelming to some. Negative attitudes towards research are often transmitted by educators through the process of socialisation into the profession (Lazar, 1990). The problem of lecturers who are not up to standard regarding their own research knowledge and skills, the heavy teaching loads of social work lecturers who have to teach both theory and practice, and the explosion of research literature which makes it increasingly difficult to keep abreast of the latest developments can be regarded as more challenges facing the profession of social work. Gaining ethical permission has been mentioned as yet another limitation concerning the research module(s).

\section{THE OPERATIONALISING OF THE RESEARCH MODULE(S)}

In this section of the report the operationalising of the research module(s) regarding its theory and practice is discussed.

- We have class discussions, small group discussions, individual supervision, workshops, role playing, library visits, internet searches, observations of projects, presentations, tests and examinations, as well as a mini-dissertation. Continuous assessment takes place in most research modules. (10)

- Students are encouraged to focus on the useful and practical parts of all aspects of the module(s) that they will need to use when they do their own research projects at their organisations during field placement; in other words, to link their project to the steps in the research project, research designs, sampling, ethics and procedures. (4) 
- We focus on the relationship between research and practice, paradigms, proposal writing, report writing, designs, methods, sampling, measurement, graphic presentation of data and research ethics. In this way the theory and practice of research can become instilled in the minds of students. (4)

- Students have to write a research proposal in the normal fashion with aspects such as problem statement, aims and methodology and a research report of between 6000 and 10000 words on a topic they would like to investigate during their four months full-time practical block placement at a particular organisation of their choice (June to September of the fourth year). They orientate themselves towards the particular organisation during a week in the April vacation. It is expected of them to do their empirical research on individual cases, a group or a community project as part of their daily functioning as a social worker at the organisation. In this way we try to integrate all the methods of social work and to operationalise the term "practitioner-researcher".

- During October of each year students are afforded the opportunity to present their projects at a research day.

The integration of various teaching skills such as group discussions and supervision is used by most lecturers. From the responses of participants it is evident that many strategies are followed to integrate the theory and practice of research for students. Writing a research proposal and a research report can be regarded as excellent ways of evaluating whether students are able to integrate theory with the practice of research.

\section{OPINIONS ON INDIVIDUAL OR GROUP PROJECTS}

- Individual student projects. (7)

- Group projects of 3-4 students per group. (5)

- Their choice - individually or in a group.

- Together in pairs.

It seems that individual projects are preferred by most departments of social work, although group projects are undertaken by a fairly large number of departments. One department gives its students the choice of working individually or in group context, and one other department lets its students work in pairs. Personally the author would recommend individual projects because of the fact that individual students' research projects can be closely monitored and objectively evaluated. It is, however, realised that with current staff-student ratios it is not always possible to conduct individual projects and alternative plans will have to be considered.

\section{DESCRIPTION OF THE CONTENT OF RESEARCH MODULE(S)}

The following content was suggested for the research module(s). It can be seen that the emphasis varies from institution to institution and that certain aspects are regarded as important by almost all, while others focus on different aspects. In accordance with the National Social Work SGB exit-level outcomes, the main aim is that by the end of this module (end of four years of study), students are expected to demonstrate the capacity to use, plan and execute social work research as well as to cultivate research-mindedness. This includes knowledge and appropriate application of the various research designs and methodologies. The following can be seen as being representative of the opinions of participants and, where literature sources are indicated, they refer to possible sources that can be utilised in certain contexts. 
- Skills in report writing. Research reports reflect knowledge of and skills in social work research, as well as display a critical appreciation of the link between knowledge construction, research and social work practice. (10)

- Research design, procedures and data-gathering methods. (9)

- The context of social work research including the orientation to research, epistemological issues (Barker, 2003:145), alternatives to scientific knowledge/the sources of knowledge (Grinnell, 2001:2-12; Jackson, 2003:5-9), approaches/paradigms, the goals of social work research (McBurney, 2001:12-23), the roles of the social work researcher and all applicable terminology/definitions which are the tools of the researcher (Gravetter \& Forzano, 2003:453-467; Mitchell \& Jolley, 2001:2-8; Monette et al., 2005:24-37). (8)

- The research process with the focus on the quantitative and qualitative paradigms. (7)

- The selection of a researchable topic and formulation of a problem statement. (7)

- To do a literature study and to integrate the theory with the empirical findings, as well as to use the library to its fullest. (7)

- Data analysis, interpretation and presentation of data. (6)

- Ethical issues. (6)

- Sampling techniques. (5)

- The methods and procedures of measurement. (5)

- The supervisory relationship. (3)

- The formulation of a research proposal. Research proposals reflect a well-formulated plan for the intended research and ethics are clearly identified and considered in the design and implementation of all research activities. (3)

- The pilot study and its various aspects as well as the value of a pilot study. (2)

- The link between the research paper, minor dissertation, dissertation, thesis and manuscript.

Although a great deal of similarity was found between the various training institutions regarding research, it remains a fact that the profession is not in complete agreement concerning the role of research in the curriculum and what should be covered in the various study units. There is much room for innovation and creativity in research and in planning these modules (Hesse-Biber \& Leavy, 2006:96). Social work research is constantly diversifying and expanding its boundaries, while the critical influence of the wider economic, political, theoretical and practice changes can also be seen in social work itself (Gibbs, 2001:687).

The enduring and ever-expanding conflicts in the ways of knowing, doing and valuing social work research, such as the role of practitioners as researchers and some research procedures, for instance, the participatory action research model with a focus on empowering, liberation and emancipation of research participants and service users as self-determining researchers (Beresford \& Evans, 1999:673; Gibbs, 2001:687) are merely a few examples. Social work research is, however, complex and multi-dimensional and remains an arena for contested and competing perspectives and practices regarding the changing nature and purpose of social work research (Gibbs, 2001:688; Powell, 2002:17).

The importance of some of these aspects of the research module such as the theoretical background, sampling, pilot study, procedures, ethical issues, quantitative and qualitative paradigm and the research process are mentioned by De Vaus (2002), Grbich (2004), Punch 
(2005), Walliman (2006) and Yates (2004). Druckman (2005:23) emphasises the importance of the literature review on a particular topic of interest - to become familiar with a body of published work is an essential task of the researcher. The literature review indicates the gaps in knowledge and enables students to learn about the methodological thinking used by others, and to develop frameworks and procedures that can organise the intended study (Druckman, 2005:23).

The utilisation of the library and website resources should form part of the research module(s). The multiple roles of the social work researcher, such as facilitator, observer, data collector, supplier of relevant knowledge, bridge builder between interested parties, and service provider during action, are important for inclusion in the research module(s) (Morris, 2006:151). Research reports should reflect knowledge of and skills in social work research, as well as display a critical appreciation of the link between knowledge construction, research and social work practice.

Most of the mentioned content for the research module(s) are confirmed by the majority of the following basic and generalist research text books such as Babbie (2007), Creswell (2003), De Vos et al. (2005), Grinnell (2001), Marlow (2005), McBurney (2001), Neuman (2003), Ritchie and Lewis (2003), Royse (2004), Rubin and Babbie (2005) and Sarantakos (2000).

Some universities submitted vague ideas on the content of the research module(s), while others could provide a brief clear-cut contextualisation (content) of their module(s). Social work educators must take the lead in installing in their students research commitment and pride. This can be done by way of teaching students the scientific method, qualitative and quantitative methodologies, and evaluation techniques and designs. Dunlap (1993:301) emphasises basic competence in statistics for students and adds that, to maximise limited instructional time in a full curriculum, statistics courses should become required prerequisites.

Research should be incorporated into all content areas, including field education. Thyer (1989) divided social work research into two equally important domains, namely practice research, meaning immediate application to the delivery of social services, and basic science studies, aimed at the development of knowledge. Students' efforts should be recognised through awards, discussions, presentation and publication (Dunlap, 1993:301).

\section{FINAL COMMENTS BY PARTICIPANTS}

\section{Participants added the following comments:}

- More uniformity between universities regarding the learning outcomes of the research module in social work is necessary. (4)

- We place a high priority on the research course. Students must have solid practical experience in research and the necessary confidence to initiate research projects without hesitation in their careers as social workers. (2)

- We need a task team to be selected at the ASASWEI business meeting to investigate the content of the research module(s) in a systematic manner. In so doing, we can reach a measure of consensus regarding the content and outcomes of the research modules. This report would be relevant at such a meeting.

- More hands-on experience in research is needed in order for students to implement the research process. 
- The research module(s) should be an integral part of the practical placements, specifically in the fourth year.

- The negative perception of students regarding the research module is problematic and ways should be sought to change this.

\section{DISCUSSION}

All lecturers of the research module(s) consider research as a non-negotiable component of the curriculum that should be presented by capable lecturers who can inspire students to become research-minded professionals who can integrate the theoretical components of research with daily practice. Many reasons can be given for the initial resistance of students to research and the general perception is that, once students have broken through the initial barriers towards executing research, they find it empowering and find that it opens up a new world of possibilities for the profession. However, solutions should be sought for the fact that very few practitioners do research after leaving the university.

Regarding the number of credits various institutions allot to the research module(s), ranging from 15 to 48, it can be said that they are not all in agreement on the importance of the research module(s), or in some cases some aspects of the research module are presented in another generic module. Most institutions offer their research module(s) at level 4 only. Seeing that the fourth year is too labour intensive, research as a new methodology should start at an earlier stage in the course, for instance, during the second semester of the third year.

Some of the challenges that were encountered in the operationalising of the research module(s) can be attributed to the poor academic preparation of students, the lack of interest in research, the difficulty in supporting large numbers of students at some universities and the fact that even some research lecturers are not motivated to teach the module(s) and lack research-mindedness. Endeavours should be made in assisting participants to recognise this negative attitude towards research in themselves. Furthermore, the fact that the fourth year is overwhelming to many students, the increase in plagiarism and the lack of a research culture at most welfare organisations can be regarded as some of the most prominent challenges in the operationalising of the research module(s) at training institutions.

As far as the operationalising of the research module(s) is concerned, most institutions utilise a variety of teaching skills such as small-group discussions, individual supervision, workshops, role playing and field observations. The focus of all these strategies is to integrate theory with practice in the minds of students in order for them to become scientific practitioner-researchers. Writing a research proposal and a research report are regarded by some institutions as an excellent way of evaluating whether students are able to integrate the theory of research with practice.

Most institutions still prefer individual research projects for their final-year students, which can be attributed to the obvious advantages of students focusing on their own projects. However, a fairly large number of institutions require their students to work in a group context as a result of the heavy work loads and other constraints. A systematic comparison between the two outcomes would be very helpful to curriculum planning.

Skills in report writing with all that it entails as well as a focus on research design, procedures and data-gathering methods are high priorities as far as the content of the research module(s) is concerned. Many participants emphasised the basic orientation and epistemological issues as the basis of the module(s), while the research process, the formulation of a problem statement, 
literature study, data analysis, interpretation and presentation of data were also mentioned by a large number of participants.

\section{RECOMMENDATIONS}

The following recommendations can be made from the findings of this study:

- Ways should be sought in which the initial resistance of students to conduct research can be dealt with, such as introducing students to the importance and accessibility of research at an early stage, demonstrating that research should be part of the everyday scientific activities of students, lecturers and practitioners such as doing an assignment, marking assignments and report writing, in order for them to become scientific practitioners.

- Greater emphasis should be placed on basic competence in statistics for students.

- In a follow-up study the viewpoints of students themselves should be investigated.

- Considering the poor academic and scientific level of most students, ways should be sought to overcome this obstacle such as a bridging course that does not necessarily have to stretch across an entire academic year.

- Capable, properly qualified, enthusiastic and research-minded lecturers, who can properly integrate the theory of research with practice, should be selected to teach the research module(s).

- Attempts should be made to assist students, lecturers and practitioners in recognising negative attitudes towards research in themselves.

- More research is needed to develop even more innovative teaching skills than are currently evident at the various institutions.

- Individual research projects for students can be recommended whenever possible in order for lecturers to scrutinise the work that a student is doing and to evaluate the research project objectively. A systematic comparison between individual and group projects would be helpful in future curriculum planning.

- Although a fair degree of consensus exists regarding the logistics of the research module(s), more uniformity is needed concerning the outcomes, content, number of credits, year level, ways of presentation of the module(s) and ways of limiting the restrictions that were mentioned by all training institutions. For this reason a task team should be selected at the ASASWEI business meeting.

\section{SUMMARY}

This investigation was based on the need to take a closer look at the research module(s) offered by South African training institutions for social work. A questionnaire was compiled and sent via e-mail to all training institutions in South Africa that offer training for social workers. A variety of qualitative questions were posed to which responses of the particular research lecturer at every institution were sought. Interesting findings on the viewpoints of lecturers and their perception of the views of their students on research and the research module(s) were obtained. Some of these views are that lecturers see research for students as a non-negotiable part of the curriculum and that students place their focus in studying social work primarily on the implementation of the primary methods of social work and not on conducting research. The number of credits, and the term, semester and level of presentation of the research module(s), as well as the matter of individual or group projects for final-year students were investigated and a wide variety of answers were given. The challenges experienced regarding the 
operationalising and the content of the research module(s) were also discussed. Here again, many challenges were mentioned but a fair degree of agreement was also found on the content of the research module(s) at the various training institutions where social workers are trained.

\section{ACKNOWLEDGEMENT}

A word of sincere thanks to the colleagues at the 14 training institutions that responded to the questionnaire. A word of special thanks is extended to Dr M de Jager who assisted in data gathering and conceptualising the initial idea of this project.

\section{REFERENCES}

BABBIE, E. 2007. The practice of social research. London: Thomson Wadsworth.

BARKER, R.L. 2003. The Social Work Dictionary. Washington: National Association of Social Workers.

BERESFORD, P. \& EVANS, C. 1999. Research note: research and empowerment. The British Journal of Social Work, 29(5):671-677.

BLESS, C. \& HIGSON-SMITH, C. 2000. Fundamentals of social research methods: an African perspective. Cape Town: Juta.

BLOOM, M., FISCHER, J. \& ORME, J.G. 1999. Evaluating practice: guidelines for the accountable professional. London: Allyn and Bacon.

COREY, G., COREY, M.S. \& CALLANAN, P. 1993. Issues and ethics in the helping professions. Pacific Grove: Brooks/Cole Publishing Company.

CRESWELL, J.W. 2003. Research design: qualitative, quantitative, and mixed methods approaches. London: Sage Publications.

DE VAUS, D.A. 2002. Research design in social research. London: Sage Publications.

DE VOS, A.S., STRYDOM, H., FOUCHÉ, C.B. \& DELPORT, C.S.L. 2005. Research at grass roots: for the social sciences and human service professions. Pretoria: Van Schaik Publishers.

DRUCKMAN, D. 2005. Doing research: methods of inquiry for conflict analysis. London: Sage Publications.

DUNLAP, K.M. 1993. A history of research in social work education: 1915-1991. Journal of Social Work Education, 29(3):293-301.

EPSTEIN, I. 1987. Pedagogy of the perturbed: teaching research to the reluctants. Journal of Teaching in Social Work, 1(1):71-89.

EVERITT, A., HARDIKER, P., LiTTlEWOOD, J. \& MULLENDER, A. 1992. Applied research for better practice. London: MacMillan Publishers.

GIBBS, A. 2001. The changing nature and context of social work research. The British Journal of Social Work, 31(5):687-704.

GLICKEN, M.D. 2003. Social research: a simple guide. New York: Allyn and Bacon.

GRAVETTER, F.J. \& FORZANO, L.B. 2003. Research methods for the behavioural sciences. London: Thomson Wadsworth Publishers.

GRBICH, C. 2004. New approaches in social research. London: Sage Publications. 
GRINNELL, R.M. 2001. Social work research and evaluation: quantitative and qualitative approaches. New York: F.E. Peacock Publishers.

GRINNELL, R.M. \& WILLIAMS, M. 1990. Research in social work: a primer. Itasca: F.E. Peacock Publishers.

HESSE-BIBER, S.N. \& LEAVY, P. 2006. Emergent methods in social research. London: Sage Publications.

JACKSON, S.L. 2003. Research methods and statistics: a critical thinking approach. London: Thomson Wadsworth.

KARGER, H. 1983. Science, research, and social work: who controls the profession? Social Work, 28(3):200-205.

KIRK, S.A. 1999. Social work research methods: building knowledge for practice. Washington: NASW Press.

LAZAR, A. 1990. Statistics courses in social work education. Journal of Teaching in Social Work, 4(1):17-31.

MARLOW, C.R. 2005. Research methods for generalist social work. London: Thomson Brooks/Cole.

McBURNEY, D.H. 2001. Research methods. London: Wadsworth Thomson Learning.

MitChell, M. \& JOLLEY, J. 2001. Research design explained. New York: Harcourt College Publishers.

MONETTE, D.R., SULLIVAN, T.J. \& DEJONG, C.R. 2005. Applied social research: a tool for the human services. London: Thomson Brooks/Cole.

MORRIS, T. 2006. Social work research methods: four alternative paradigms. London: Sage Publications.

NEUMAN, W.L. 2003. Social research methods: qualitative and quantitative approaches. New York: Allyn and Bacon.

NEW DICTIONARY OF SOCIAL WORK. 1995. Terminology Committee for Social Work. Cape Town: CTP Book Printers.

POWELL, J. 2002. The changing conditions of social work research. The British Journal of Social Work, 32(1):17-33.

PUNCH, K.F. 2005. Survey research: the basics. London: Sage Publications.

RITCHIE, J. \& LEWIS, J. 2003. Qualitative research practice. London: Sage Publications.

ROYSE, D. 2004. Research methods in social work. London: Thomson Brooks/Cole.

RUBIN, A. \& BABBIE, E.R. 2005. Research methods for social work. London: Thomson Brooks/Cole.

SALES, E., LICHTENWALTER, S. \& FEVOLA, A. 2006. Secondary analysis in social work research education: past, present, and future promise. Journal of Social Work Education, 42(3):543-558.

SARANTAKOS, S. 2000. Social research. South Yarra: MacMillan Education Australia. 
STRYDOM, H. 1997. Maatskaplike werkers se betrokkenheid by en houding oor navorsing. [Social workers' involvement in and attitude towards research.] Social Work/Maatskaplike Werk, 33(2):120-135.

STRYDOM, H. 1998a. 'n Profiel van maatskaplike werkers en opleiding in navorsing. [A profile of social workers and training in research.] The Social Work PractitionerResearcher/Die Maatskaplikewerk-Navorser-Praktisyn, 11(1):53-68.

STRYDOM, H. 1998b. Trends in the South African social work research field. Social Work/Maatskaplike Werk, 34(1):44-58.

THYER, B. 1989. First principles of practice research. The British Journal of Social Work, 19(4):309-323.

TRIPODI, T. \& EPSTEIN, I. 1978. Incorporating knowledge of research methodology into social work practice. Journal of Social Service Research, 2(1):65-78.

WALLIMAN, N. 2006. Social research methods. London: Sage Publications.

WEINBACH, R. \& RUBIN, A. 1980. Teaching social work research: alternative programs and strategies. New York: Council on Social Work Education.

YATES, S.J. 2004. Doing social science research. London: Sage Publications.

Prof Herman Strydom (PhD), Chairperson, School of Psycho-Social Behavioural Sciences: Section Social Work, North-West University, Potchefstroom Campus, Potchefstroom, South Africa. 